Book review

\title{
Governments, Competition and Utility Regulation
}

Colin Robinson (ed.)

Reviewed by

S K Sarkar

Director, Regulatory Studies and Governance Division

The Energy and Resources Institute, New Delhi

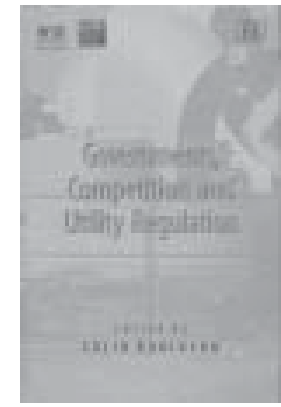

Hardbound

247 pp. 2005

ISBN 1845422090

International Journal of Regulation and Governance 6(2): 209-214

The book contains nine papers, which are based on the thirteenth Beesley lectures on Regulation (2003) - four each on competition-related issues and utility regulations, and one on emissions trading. T he nine papers dealing with (1) competition policy and trade, (2) antitrust and consumer welfare, (3) merger control and efficiency, (4) emissions trading, (5) Ofcom and convergence, (6) energy regulation and competition, (7) regulating the $L$ ondon $U$ nderground, (8) the future of water regulation, and (9) European merger control, are commented upon by experts in the concerned fields.

On the subject of competition, issues on transnational cartels are discussed first. Selected countries' experiences show that the globalization of economies is unfortunately accompanied by the anti-competitive practices being resorted to by some MNCs (multinational companies) especially in sectors such as aluminium (in the U S [U nited States]) and cement (in Egypt). The national competition authorities have limited geographical jurisdiction over the international players resorting to such practices. For addressing this issue, the possible solutions are: reliance on approach for policing international anti-competitive practices (such as in the US and the EU [European Union]); bilateral voluntary or regional cooperation between competition authorities (for example, between $\mathrm{C}$ anada and $\mathrm{C}$ hile); or creation of a supranational body of law and a supranational 
enforcing authority (as in the EU ). Some of these solutions may not work in the context of a developing country. For example, bilateral agreements on competition matters among national governments may not be feasible due to conflicting trade interests. A nother solution could be resorting to a multilateral WTO (World Trade Organization) umbrella. However, reaching such solutions or agreements on cartels and related competition questions is often difficult (for example, none of the Singapore issues made any progress in the ministerial meeting of $C$ ancun). This often calls for adopting a consensus-based incremental approach. In the Indian context, given the recently created Competition Commission under the Competition Act 2002, albeit non-functional, these lessons provide guidance the Commission and policy-makers in their future endeavours.

To prevent anti-competitive practices, many countries including the U S adopted an antitrust policy. A study on whether the Sherman Antitrust Act, 1890, and the Clayton Antitrust Act, 1914, have enhanced consumer welfare in the US, shows that the welfare increase is not universal. The reasons, inter alia, are delay in the settlement of monopolization cases, and the power of the market in eventually curbing anti-competitive practices. It is, however, not easy to formulate and implement effective antitrust policies in a dynamic competitive economy characterized by rapid technological changes, and a newly introduced intellectual property regime. The antitrust authority may consider focusing on the most significant violations, such as blatant price fixing, and treat the most apparent threats to competition with 'benign neglect'.

An empirical analysis of the merger laws in the US and the UK (U nited K ingdom) has shown that this component of the competition policy did not result in an increase in consumer welfare either. Thus, one may conclude that this should be banned and the competition authority should only prohibit mergers where 'expost' remedies are not effective. For the remaining cases, they could wait till there is evidence of consumer welfare losses. H owever, reality much of the potential danger of a merger could not be tackled 'expost' by an Article 82 (abuse of dominance) case.

On merger control procedures, the EU's example shows that there is a need for better understanding and treatment of efficiencies for improving the procedure, as the present $E U$ 
system is likely to allow anti-competitive mergers (Type II error), as well as to prohibit pro-competitive mergers (Type I error). Understanding the evaluation of synergies and the method to evaluate it should be a part of the EU merger reforms. Reallocation of a firm's intangible assets could be an important source of synergies. In particular, the synergy could be assessed by directing firms to submit their plans for the integration of assets. In the UK, some of these principles are already being followed. For example, efficiency assessments are being carried out by OFT (Office of Fair Trading) using two criteria: is the merger case likely to be a case of the SLC (substantial lessening of competition), and whether, even in case of an adverse SL C verdict, the consumer would benefit or not.

The book discusses the multi-sector regulatory mechanism adopted in the UK and Germany. The UK's Ofcom (Office of Communications) combines the work of five erstwhile regulators: Independent Television Commission, Broadcasting Standards Commission, Radio Authority, Oftel (Office of Telecommunications), and Radio Communications Agency. T he telecom/spectrum regulation looks at market developments from a competition-based and economic point of view, while content regulation deals with the plurality of programmes that are counter to the purely economic aspects. Ofcom is supervised by the Department of Trade and Industry and the D epartment of Culture, M edia, and Sports. It has four functional departments: (1) strategy and market development, (2) competition and markets, (3) contents and standards, and (4) operations. Since conduit regulation is market-driven and content regulation is associated with significant public interest, conflicts of interest may arise in the UK's new regulatory process. However, there are advantages as well, because knowledge of content regulation can help in determining obligations, such as access to CAS (conditional access service), APIs (Application Programme Interfaces), or EPGs (E lectronic Programme Guides). The merger of the five regulatory bodies is prone to managerial diseconomies.

O fcom's German counterpart, R egT P (Regulierungsbehörde für Telekommunikation und Post [T he German Federal Regulatory Authority for Telecommunication and Postal M arkets], is responsible for regulating the energy and telecom sectors. Content regulation, however, is the responsibility of the states. The regulator, being overseen by the $\mathrm{M}$ inistry of Economics and Labour, has only two departments: (1) planning and 
licensing of frequencies and (2) market surveillance (similar to Ofcom's operations department). In Germany, the 'mustcarry obligations' are determined by the government, while RegT $P$ is in charge of determining the rates for the use of the transmission network for CAS, etc. Although the scope of RegTP's focus is very wide, the merger approach of the unrelated sectors (for example, energy, and post and electronic communications sectors) into a single regulatory body is not worth emulating in other countries. In the Indian context, debate continues regarding the efficacy and feasibility of having multisectoral regulators in sectors such as energy as well as telecom and broadcasting without any clear consensus.

The book touches upon the dispute resolution procedure in LUL (London U nderground Ltd) wherein a PPP (public-private partnership) arbiter was appointed. The arbiter, however, has a restrictive role, has a approach, and provides guidance or directions only when required to by the contracting parties. T he PPP arrangements for $L U L$ are framed to be more robust than those of the UK's national rail network and have a clear customer focus. This regulatory contract is different from the licensing system used under the utility regulation. F or example, while a license could be modified by the regulator at any time, under PPP arrangements this can only be undertaken after a certain period-in the case of $L U L$, seven and a half years.

In addition to its electricity and telecom sectors, the UK's water industry is also regulated. T his sector witnessed the emergence of average or highly-leveraged firms, although they started as lowly-leveraged firms during privatization. I nitially, the earnings were high and the tax advantages of debt were modest, leading to a low-leverage level. Later, in response to higher regulation, less favourable treatment of tax on equity, and introduction of higher governance control, the leverage level went up. $T$ his trend has resulted in the reduction of the cost of capital to water companies due to reduced exposure to regulatory and managerial risks, private cost of capitals incurred by the investor being different from the social cost borne by consumers; and the problem of modern investment. In the long run, the 'equity model' could be a viable model for ensuring smooth firm-regulator relations. Disagreeing on this issue, Philip Fletcher, the UK's D irector-General of Water Services, noted that his ability to regulate the water industries is not constrained by the higher 
levels of their gearing. In fact, there are huge turnovers in the UK's water industry through mergers, acquisitions, and consolidations and restructuring, irrespective of high gearing.

The book devotes the chapter ' $O$ ur energy future - creating a low carbon economy' to a discussion of the UK White Paper (2003), which outlines two policy goals: (1) control of Carbon dioxide emissions (by following a path to cut these emissions by some $60 \%$ by about 2050, with real progress by 2020), and (2) maintenance of the security of energy supply. To achieve these goals, the government set certain fuel targets (for example, renewable supply up to $10 \%$ of the electricity in 2010 , subject to the costs being acceptable by consumers, with a doubling of the target to $20 \%$ by 2020 ), proposed energy demand reductions in various sectors, and planned certain activities (such as the achievement of $10 \mathrm{G} \mathrm{W}$ [gigawatt] of good quality combined hydro power generation of electricity by 2010). T he author argues that this policy could affect the competitive gas and electricity markets, raise consumer prices, and prevent competition-an approach that conflicts with the spirit of independent economic regulation. Alternatively, a market-driven approach to the reduction of carbon emissions by allowing a carbon trading scheme has been suggested for achieving the environmental goals.

Further analysis of the UK and the EU emissions trading system (for example, allowance trading and baseline and credit trading) has shown that these markets are growing, like in the US or China. The size of the EU emissions market is expected to grow tremendously. Compared to the UK (the UK emissions trading scheme was launched in M arch 2002 in which the direct participants - some 33 organizations voluntarily undertook emission reduction targets to reduce their emissions below 1998-2000 levels), the EU scheme of 2005 (under which all the EU governments are required to set an emission cap for all installations covered by the scheme, each installation is allocated allowances for a particular commitment period, and the number of allowances allocated to each installation for a given period is determined on the basis of the $\mathrm{N}$ ational Allocation Plan) is mandatory and is expected to have far reaching effects. $\mathrm{M}$ any large industrial plants in the EU have joined the scheme since January 2005, although some business circles criticized that this measure may reduce the $\mathrm{EU}$ member countries' global competitiveness. 
$M$ any of the issues dealt with in the book are new to India and the other South Asian countries. However, they are issues that these countries are likely to face in a mature regime of competition, independent regulation, or emission trading. Given the nascent development of these areas, the book provides an indepth understanding of a subject that helps analyse critical issues in these countries. 